\title{
Expression Analysis of the Long Non-Coding RNA LINC01433 in Lung Cancer
}

\section{Analýza exprese dlouhé nekódující RNA LINC01433 u karcinomu plic}

\author{
Niazi ${ }^{1}$ Z. ${ }^{1,2}$, Garazhian E. ${ }^{1,2}$, Esfandi F. ${ }^{3}$, Hassani Z. M. ${ }^{3,4}$, Taheri M. ${ }^{5}$, Ghafouri-Fard S. ${ }^{6}$ \\ 1 Department of Basic Medical Sciences, Neyshabur University of Medical Sciences, Neyshabur, Iran \\ ${ }^{2}$ Neyshabur Endemic Diseases Research Center, Neyshabur University of Medical Sciences, Neyshabur, Iran \\ ${ }^{3}$ Geniran Lab, Tehran, Iran \\ ${ }^{4}$ Department of Cell and Molecular Biology, Faculty of Life Sciences, Kharazmi University, Tehran, Iran \\ ${ }^{5}$ Urogenital Stem Cell Research Center, Shahid Beheshti University of Medical Sciences, Tehran, Iran \\ ${ }^{6}$ Department of Medical Genetics, Shahid Beheshti University of Medical Sciences, Tehran, Iran
}

\begin{abstract}
Summary
Background: Lung cancer is one of the most fatal human cancers both in males and females. This type of cancer is categorized to different subtypes among them is non-small cell lung cancer (NSCLC). NSCLC accounts for about $80 \%$ of all cases. Long non-coding RNAs (IncRNAs) have been shown to influence the pathogenic course of lung cancer. However, the contribution of LINC01433 IncRNA in this type of cancer in Iranian patients is not clear. Purpose: In the current project, we evaluated expression of LINC01433 in 42 NSCLC samples and their paired non-tumoral tissues using quantitative real time polymerase chain reaction method. Samples were collected from patients admitted to Labbafinejad Hospital during 2016-2017. Results: There was no significant difference in the expression of LINC01433 between tumoral and non-tumoral tissues (expression ratio $0.67, p=0.42$ ). Expression of this IncRNA was not associated with any of clinical and demographic data including age, gender, smoking history, stage or cancer subtype. Conclusion: Based on the similar expression levels of this IncRNA between tumoral and non-tumoral tissues and lack of association between expression levels and clinical data, this IncRNA is not a possible contributor to lung cancer in Iranian patients. However, expression analysis of this IncRNA in larger sample sizes is needed to verify our results.
\end{abstract}

Key words

lung cancer - expression - long non-coding RNA

\section{Souhrn}

Východiska: Karcinom plic je jedním z nejfatálnějších karcinomů jak u mužů, tak u žen. Tento typ karcinomu je rozdělen do různých podtypů, $\mathrm{k}$ nimž patří nemalobuněčný karcinom plic (non-small cell lung cancer - NSCLC). NSCLC představuje asi $80 \%$ všech případů. Bylo prokázáno, že dlouhé nekódující RNA (long non-coding RNA - IncRNA) ovlivňují patogenezi karcinomu plic. Vliv IncRNA LINC01433 na tento typ karcinomu u íránských pacientů však není jednoznačný. Cíl: V tomto projektu jsme pomocí kvantitativní polymerázové řetězové reakce $v$ reálném čase vyhodnotili expresi LINC01433 ve 42 vzorcích NSCLC a jejich párových nenádorových tkáních. Vzorky byly odebrány od pacientů prijiatých do nemocnice Labbafinejad v letech 2016-2017. Výsledky: Nebyl nalezen žádný významný rozdíl v expresi LINC01433 mezi nádorovými a nenádorovými tkáněmi (poměr exprese 0,$67 ; p=0,42$ ). Exprese této IncRNA nebyla spojena s žádnými klinickými a demografickými údaji vč. věku, pohlaví, historie kouření, stadia nebo podtypu karcinomu. Závěr: Na základě podobných hladin exprese této IncRNA mezi nádorovými a nenádorovými tkáněmi a chybějící asociace mezi hladinami exprese a klinickými údaji nemá tato IncRNA vliv na karcinom plic u íránských pacientů. K ověření našich výsledků je však nutná analýza exprese této IncRNA na větším vzorku pacientů.

Klíčová slova

karcinom plic - exprese - dlouhé nekódující RNA
The authors declare they have no potential conflicts of interest concerning drugs, products, or services used in the study.

Autoři deklarují, že $v$ souvislosti s predmětem studie nemají žádné komerční zájmy.

The Editorial Board declares that the manuscript met the ICMJE recommendation for biomedical papers.

Redakční rada potvrzuje, že rukopis práce splnil ICMJE kritéria pro publikace zasílané do biomedicínských časopisů.

$\equiv$

Mohammad Taheri, MD, PhD Urogenital Stem Cell Research Center

Shahid Beheshti University of Medical Sciences

Bldg No. 2 SBUMS

Arabi Ave, Daneshjoo Blvd, Velenjak Tehran, Iran

e-mail:mohammad_823@yahoo.com

Soudeh Ghafouri-Fard, MD, PhD

Department of Medical Genetics Shahid Beheshti University of Medical Sciences Bldg No. 2 SBUMS

Arabi Ave, Daneshjoo Blvd, Velenjak Tehran, Iran

e-mail: s.ghafourifard@sbmu.ac.ir

Submitted/Obdrženo: 18. 6. 2019

Accepted/Přrijato: 8. 8. 2019 


\section{Introduction}

Lung cancer is one of the most fatal human cancers accounting for the first cause of cancer-related mortality in male and the second one in female patients [1]. This type of cancer is categorized based on the histological features to non-small cell lung cancer (NSCLC) and small cell lung cancer. The major types of NSCLC are adenocarcinoma, squamous cell carcinoma and large cell carcinoma [2]. Based on the close relationship between cancer stage and overall survival [3], biomarkers for early diagnosis of lung cancer are needed. Expression profiling of tumoral tissues vs. non-tumoral tissues is expected to facilitate identification of such biomarkers. Long non-coding RNAs (IncRNAs) include a major part of human gene transcripts. Their participations in various cellular processes, for instance proliferation, metastasis and stem cell renewal, has potentiated them as diagnostic biomarkers in NSCLC [4]. We have recently reported dysregulation of some IncRNAs in NSCLC tissues of Iranian patients $[5,6]$. A previous study, which aimed at identification of lung-cancer-related IncRNAs, has detected alterations in IncRNA profile in the human bronchial epithelial cell line after transformation of cells by antibenzo(a) pyrene-7,8-diol-9,10-epoxide. Among the altered IncRNAs was the long intergenic non-protein coding RNA 1433 (LINC01433 or alternatively named LOC728228). This IncRNA has been upregulated in transformed cells compared with control untransformed cells [7]. Its silencing has suppressed cell proliferation, induced cell-cycle arrest, inhibited cellular migration and repressed tumorigenic potential both in vitro and in vivo. Consequently, author suggested this IncRNA as an oncogenic IncRNA in lung cancer [7]. A recent study has reported over-expression of LINC01433 in NSCLC samples compared with the normal non-tumoral tissues. Their in vitro experiments also verified the results of the previous study regarding the oncogenic role of this IncRNA [8]. Based on these studies, we aimed to confirm these results in Iranian NSCLC patients. Therefore, we designed the current investigation to compare expression of LINC01433 between tumoral and nontumoral tissues from NSCLC patients.

\section{Materials and Methods \\ Patients}

Forty-two patients with NSCLC have been enrolled in the current study. Patients were referred to the Labbafinejad Hospital during 2016-2017. Tumoral and non-tumoral samples were gathered prior to radio/chemotherapy from each person. Informed consent forms were obtained from all study participants. The study protocol was approved by the local ethical committee.

\section{Expression assays}

Total RNA was isolated from tumoral and non-tumoral tissues using the TRIzol $^{\mathrm{TM}}$ material (Invitrogen, Carlsbad, CA, USA). Next, the quantity and quality of the extracted RNA was appraised using NanoDrop equipment (Thermo Scientific, USA). The ratio of absorbance at $260 \mathrm{~nm}$ and $280 \mathrm{~nm}$ was measured. The ratios between 1.8-2.0 were regarded as acceptable for further steps. The High-Capacity cDNA Reverse Transcription Kit (Applied Biosystems, Foster City, CA, USA) was used for complementary DNA (cDNA) production. Approximately $500 \mathrm{ng}-1 \mu \mathrm{g}$ of RNA was reverse transcribed. Then 20-40 ng of the synthesized CDNA was used for each reaction. Transcript levels

Tab. 1. The sequences of primers used for assessment of LINC01433 levels.

\begin{tabular}{l|c|c|}
\hline Primer & \multicolumn{1}{c|}{ Sequence } & Product size (bp) \\
\hline$B 2 M F$ & AGATGAGTATGCCTGCCGTG & 105 \\
\hline$B 2 M R$ & GCGGCATCTTCAAACCTCCA & \\
\hline LINCO1433F & AGACAGTAGCAGCCACCTTC & 123 \\
\hline LINC01433R & AACAACCGCTAGTGCATGAC & \\
\hline
\end{tabular}

of LINC01433 were compared between tumoral and non-tumoral tissues in Real-Time PCR System. B2M was used as the endogenous control. Each run had a no template control (comprised of all polymerase chain reaction reagents and primers but no cDNA template) used as negative control. Moreover, a positive control was included in each run. All reactions were performed in duplicate. The nucleotide sequences of primers are shown in Tab. 1.

\section{Statistical analysis}

Transcript levels of LINC01433 were compared between tumoral and non-tumoral considering the efficiency values. The association between LINC01433 expression and clinicipathologic data was appraised using Chi-square test. Statistical analyses were executed in SPSS Statistics version 18 (Chicago, IL, USA).

\section{Results}

General data of patients

General information of patients is summarized in Tab. 2.

\section{Expression assay}

There was no significant difference in the expression of LINC01433 between tumoral and non-tumoral tissues (expression ratio $0.67, p=0.42$ ). Expression of this IncRNA was not associated with any

Tab. 2. General information of patients.

\begin{tabular}{|c|c|c|}
\hline \multicolumn{2}{|c|}{ Parameters } & Values \\
\hline \multicolumn{2}{|l|}{ age } & $\begin{array}{c}57 \pm 8.78 \\
(37-80)\end{array}$ \\
\hline \multirow{2}{*}{ gender } & male & $73.8 \%$ \\
\hline & female & $26.2 \%$ \\
\hline \multirow{3}{*}{ stage } & I & $19 \%$ \\
\hline & II & $38.1 \%$ \\
\hline & III & $42.9 \%$ \\
\hline \multirow{2}{*}{ smoking } & yes & $83.3 \%$ \\
\hline & no & $16.7 \%$ \\
\hline \multirow{2}{*}{ subtype } & $\begin{array}{l}\text { adeno- } \\
\text { carcinoma }\end{array}$ & $57.1 \%$ \\
\hline & $\begin{array}{l}\text { squamous cell } \\
\text { carcinoma }\end{array}$ & $42.9 \%$ \\
\hline
\end{tabular}


of clinical and demographic data including age, gender, smoking history, stage or cancer subtype. Tab. 3 shows the results of association analysis between expression levels of LINC01433 and patients' characteristics.

\section{Discussion}

LncRNAs have been regarded as crucial regulators of cell survival and apoptosis in different tissues such as lung tissue. Among IncRNAs with putative roles in lung carcinogenesis are long intergenic RNAs. Zhao et al. reported significant up-regulation of LINC00152, LINC00691 and LINC00578 in lung cancer tissues. They also demonstrated down-regulation of LINC00668, LINC00710 and LINC00607 in these tissues compared with paired non-tumoral tissues [9]. Another long intergenic RNA with possible participation of lung carcinogenesis has been LINC01433. Two independent groups have demonstrated oncogenic roles of this IncRNAs via in vitro assays $[7,8]$. Moreover, the results of in vivo experiments support such role in animal models [7]. LINC01433 upregulation in cancer cell lines has enhanced cell proliferation, migration, and invasion, and induced epithelial-mesenchymal transition [8]. Based on these studies, we supposed that expression of LINC01433 would be higher in tumoral tissues obtained from Iranian NSCLC patients as well. However, expression assays indicated similar expression levels of this IncRNAs between tumoral and non-tumoral tissues of these patients. The discrepancy between our results and the results of Qian et al. study [8] might be due to different origin of included patients and their dissimilar genetic background. Consequently, we propose conduction of expression assays in samples from different ethnic groups to unravel whether genetic/environmental factors contribute in dysregulation of expression of this IncRNA. Similar to our results, Qian et al. did not report any association between expression of LINC01433 and any of clinical data including tumor size, lymph node metastasis and clinical stage [8], which reduces the possibility of participa-

Tab. 3. The results of association analysis between expression levels of LINC01433 and patients' characteristics.

\begin{tabular}{|c|c|c|c|}
\hline Parameters & $\begin{array}{l}\text { LINC01433 } \\
\text { up-regulation }\end{array}$ & $\begin{array}{c}\text { LINC01433 } \\
\text { down-regulation }\end{array}$ & p-value \\
\hline \multicolumn{3}{|l|}{ age } & \multirow{3}{*}{0.8} \\
\hline$>60$ & $8(36.4 \%)$ & $14(63.6 \%)$ & \\
\hline$\leq 60$ & $8(40 \%)$ & $12(60 \%)$ & \\
\hline \multicolumn{3}{|l|}{ gender } & \multirow{3}{*}{0.89} \\
\hline female & $12(38.7 \%)$ & $19(61.3 \%)$ & \\
\hline male & $4(36.4 \%)$ & $7(63.6 \%)$ & \\
\hline \multicolumn{3}{|l|}{ smoking } & \multirow{3}{*}{0.69} \\
\hline yes & $14(40 \%)$ & $21(60 \%)$ & \\
\hline no & $2(28.6 \%)$ & $5(71.4 \%)$ & \\
\hline \multicolumn{3}{|l|}{ stage } & \multirow{4}{*}{0.2} \\
\hline I & $1(12.5 \%)$ & 7 (87.5\%) & \\
\hline II & $8(50 \%)$ & $8(50 \%)$ & \\
\hline III & 7 (38.9\%) & $11(61.1 \%)$ & \\
\hline \multicolumn{3}{|l|}{ subtype } & \multirow{3}{*}{0.93} \\
\hline adenocarcinoma & 9 (37.5\%) & $15(62.5 \%)$ & \\
\hline squamous cell carcinoma & 7 (38.9\%) & $11(61.1 \%)$ & \\
\hline
\end{tabular}

tion of this IncRNA in the pathogenesis of lung cancer. However, Qian et al. reported association between expression of LINC01433 and smoking history [8], which was not revealed in our study.

In brief, our study did not verify the overexpression of LINC01433 in NSCLC Iranian patients despite the reported oncogenic role of this IncRNA. In our recent study of assessment of OIP5-AS1 expression in lung cancer tissues, we also reported down-regulation of this IncRNA [5], despite the reported oncogenic role of OIP5-AS1 in other studies [10]. Such results necessitate assessment of expression profile of genes in each ethnic group and potentiate the contribution of genetic/environmental factors in regulation of gene expression in tumoral tissues. Consequently, this note should be considered in adoption of transcript biomarkers for detection of cancer.

\section{References}

1. Mao Y, Yang D, He J et al. Epidemiology of lung cancer. Surg Oncol Clin N Am 2016; 25(3): 439-445. doi: 10.1016/ j.soc.2016.02.001.
2. Zarogoulidis K, Zarogoulidis P, Darwiche K et al. Treatment of non-small cell lung cancer (NSCLC). J Thorac Dis 2013; 5 (Suppl 4): S389-S396. doi: 10.3978/j.issn.20721439.2013.07.10.

3. Chansky K, Sculier JP, Crowley JJ et al. The International Association for the Study of Lung Cancer Staging Project: prognostic factors and pathologic TNM stage in surgically managed non-small cell lung cancer. J Thorac Oncol 2009; 4(7): 792-801. doi: 10.1097/JTO.0b013e3181a7716e. 4. Lu T, Wang YY, Chen D et al. Potential clinical application of IncRNAs in non-small cell lung cancer. Onco Targets Ther 2018; 11: 8045-8052. doi: 10.2147/Ott.S178431. 5. Esfandi F, Kholghi Oskooei V, Taheri F et al. Expression analysis of OIP5-AS1 in non-small cell lung cancer. Klin Onkol 2018; 31(4): 260-263. doi: 10.14735/amko2018260. 6. Esfandi F, Taheri M, Omrani MD et al. Expression of long non-coding RNAs (IncRNAs) has been dysregulated in non-small cell lung cancer tissues. BMC cancer 2019; 19(1): 222. doi: 10.1186/s12885-019-5435-5.

7. Hu G, Yang T, Zheng J et al. Functional role and mechanism of IncRNA LOC728228 in malignant $16 \mathrm{HBE}$ cells transformed by anti-benzopyrene-trans-7,8-dihydrodiol-9,10-epoxide. Mol Carcinog 2015; 54 (Suppl 1): 192204. doi:10.1002/mc.22314.

8. Qian B, Wang X, Mao C et al. Long non-coding RNA linc01433 promotes migration and invasion in non-small cell lung cancer. Thorac Cancer 2018; 9(5): 589-597. doi: 10.1111/1759-7714.12623.

9. Zhao B, Xu H, Ai X et al. Expression profiles of long noncoding RNAs in lung adenocarcinoma. Onco Targets Ther 2018; 11: 5383-5390. doi:10.2147/OTT.S167633.

10. Wang $M$, Sun $X$, Yang $Y$ et al. Long non-coding RNA OIP5-AS1 promotes proliferation of lung cancer cells and leads to poor prognosis by targeting miR-378a-3p. Thorac Cancer 2018; 9(8): 939-949. doi: 10.1111/1759-7714.12767. 